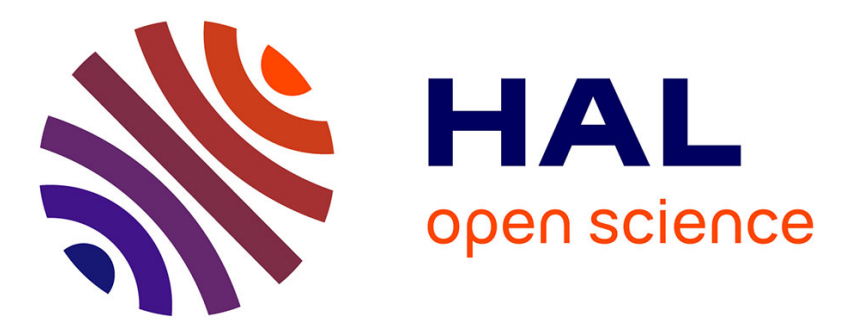

\title{
Glacier melt, air temperature, and energy balance in different climates: The Bolivian Tropics, the French Alps, and northern Sweden
}

\author{
Jean-Emmanuel Sicart, Regine Hock, Delphine Six
}

\section{To cite this version:}

Jean-Emmanuel Sicart, Regine Hock, Delphine Six. Glacier melt, air temperature, and energy balance in different climates: The Bolivian Tropics, the French Alps, and northern Sweden. Journal of Geophysical Research: Atmospheres, 2008, 113 (D24113), 1 à 11 p. 10.1029/2008JD010406 . insu00381076

\section{HAL Id: insu-00381076 https://hal-insu.archives-ouvertes.fr/insu-00381076}

Submitted on 5 Mar 2021

HAL is a multi-disciplinary open access archive for the deposit and dissemination of scientific research documents, whether they are published or not. The documents may come from teaching and research institutions in France or abroad, or from public or private research centers.
L'archive ouverte pluridisciplinaire HAL, est destinée au dépôt et à la diffusion de documents scientifiques de niveau recherche, publiés ou non, émanant des établissements d'enseignement et de recherche français ou étrangers, des laboratoires publics ou privés. 


\title{
Glacier melt, air temperature, and energy balance in different climates: The Bolivian Tropics, the French Alps, and northern Sweden
}

\author{
Jean Emmanuel Sicart, ${ }^{1}$ Regine Hock, ${ }^{2,3}$ and Delphine Six $^{4}$ \\ Received 13 May 2008; revised 18 August 2008; accepted 18 September 2008; published 23 December 2008.
}

[1] This study investigates the physical basis of temperature-index models

for three glaciers in contrasting climates: Zongo $\left(16^{\circ} \mathrm{S}, 5050 \mathrm{~m}\right.$, Bolivian Tropics),

St Sorlin $\left(45^{\circ} \mathrm{N}, 2760 \mathrm{~m}\right.$, French Alps), and Storglaciären $\left(67^{\circ} \mathrm{N}, 1370 \mathrm{~m}\right.$, northern

Sweden). The daily energy fluxes were computed during melt seasons and correlated with each other and with air temperature on and outside the glacier. The relative contribution of each flux to the correlations between temperature and melt energy was assessed. At Zongo, net short-wave radiation controls the variability of the energy balance and is poorly correlated to temperature. On tropical glaciers, temperature remains low and varies little, melt energy is poorly correlated to temperature, and degree-day models are not appropriate to simulate daily melting. At the yearly scale, the temperature is better correlated to the mass balance because it integrates the ablation and the accumulation processes over a long time period. At Sorlin, the turbulent sensible heat flux is greater because of higher temperatures, but melt variability is still controlled by short-wave radiation. Temperature correlates well with melt energy mainly through short-wave radiation, probably because of diurnal advection of warm air from the valley. At Storglaciären, high correlations between temperature and melt energy result from substantial variability of the sensible and latent heat fluxes (which both supply energy to the glacier), and their good correlations with temperature. In the three climates, long-wave irradiance is the main source of energy, but its variability is small and poorly correlated to the temperature mainly because cloud emissions dominate its variability.

Citation: Sicart, J. E., R. Hock, and D. Six (2008), Glacier melt, air temperature, and energy balance in different climates: The Bolivian Tropics, the French Alps, and northern Sweden, J. Geophys. Res., 113, D24113, doi:10.1029/2008JD010406.

\section{Introduction}

[2] In mountain and high-latitude regions, glaciers store water as snow or ice on various time scales from months to centuries (or more). Typical characteristics of glacier runoff involve marked melt-induced diurnal cycles and a concentration of annual flow during the melt season [Hock, 2003]. The glacier melt is controlled by the atmospheric energy fluxes, which are nonlinearly linked to the air temperature. The turbulent sensible heat flux depends on the temperature gradient between ice and air. The turbulent latent heat flux depends on air humidity, which is limited by saturation humidity, which in turn is a function of temperature only. The static stability of the air above a glacier's surface increases with rising air temperature, reducing the turbulent convection. The clear-sky long-wave irradiance depends mainly on the humidity and temperature of the near-surface

\footnotetext{
${ }^{1}$ Great Ice-IRD, Case MSE, Université Montpellier II, Montpellier, France.

${ }^{2}$ Geophysical Institute, University of Alaska, Fairbanks, Alaska, USA.

${ }^{3}$ Department of Earth Sciences, Uppsala University, Uppsala, Sweden.

${ }^{4}$ Laboratoire de Glaciologie et Géophysique de l'Environnement, University Joseph Fourier, Grenoble, France.
}

Copyright 2008 by the American Geophysical Union. 0148-0227/08/2008JD010406 layer of the atmosphere. Air weakly absorbs solar irradiance, but aerosol absorption near the surface can affect air temperature [e.g., Meesters et al., 1997]. The atmospheric temperature controls the precipitation phase: rain or snow, and the surface albedo can be linked to the air temperature during precipitations.

[3] Numerous studies have revealed a high correlation between glacier or snow melt and air temperature [e.g., $\mathrm{La}$ Casinière de, 1974; Zuzel and Cox, 1975; Braithwaite, 1981]. Since the mean daily temperature includes the night, whereas melting occurs mostly during the daytime, the temperature maximum has sometimes been considered a better index of melting [e.g., U.S. Army Corps of Engineers, 1956]. However, La Casinière de [1974] and Granger and Male [1978] noted that the nocturnal cooling of the surface can delay the diurnal melting and must be accounted for in melt calculations. Martin [1977], Granger and Male [1978], and Lang and Braun [1990] observed that melting is better correlated to the air temperature measured some distance away from the glacier or snow field, in part because of the thermal damping effect of the ice.

[4] These correlations provide the basis for degree-day models, which relate the melt rate to the sum of positive temperatures, generally at a daily time scale, through a constant degree-day factor. The degree-day factor depends on the relative importance of each energy flux and generally 
Table 1. Characteristics of the Study Sites and the Automatic Weather Stations

\begin{tabular}{lccccc}
\hline \multicolumn{1}{c}{ Glacier } & Location & Size $\left(\mathrm{km}^{2}\right)$ & $\begin{array}{c}\text { Altitude of AWS } \\
(\mathrm{m} \text { asl })\end{array}$ & $\begin{array}{c}\text { Altitude of } T_{\text {out }}{ }^{\mathrm{b}} \\
(\mathrm{m} \text { asl })\end{array}$ & Study Periods $^{\mathrm{c}}$ \\
\hline Zongo & $\begin{array}{c}\text { Bolivian Andes } \\
\left(16^{\circ} 15^{\prime} \mathrm{S}\right)\end{array}$ & 2.2 & 5050 & $4750(1 \mathrm{~km})^{\mathrm{d}}$ & $01.11 .1997-31.03 .1998$ \\
St Sorlin & $\begin{array}{c}\text { French Alps } \\
\left(45^{\circ} 00^{\prime} \mathrm{N}\right)\end{array}$ & 3.0 & 2760 & $2710(0.7 \mathrm{~km})$ & $01.11 .1999-21.12 .1999$ \\
Storglaciären & $\begin{array}{c}\text { Sweden } \\
\left(67^{\circ} 55^{\prime} \mathrm{N}\right)\end{array}$ & 3.1 & 1370 & $1135(1 \mathrm{~km})$ & $09.07 .2006-27.08 .2006$ \\
\hline
\end{tabular}

\footnotetext{
${ }^{\mathrm{a}}$ Automatic weather station on the glacier.

${ }^{\mathrm{b}}$ Temperature measurement outside the glacier.

${ }^{\mathrm{c}}$ Day.month.year.

${ }^{\mathrm{d}}$ Distance of $T_{\text {out }}$ from the glacier.
}

is specific to the site and to the period considered. Published values of degree day factors cover a large range of variation: from 2 to $20 \mathrm{~mm}$ day ${ }^{-1}{ }^{\circ} \mathrm{C}^{-1}$, with no clear regional pattern [Hock, 2003]. One method to improve the model's performance is to introduce spatial and/or temporal variations of the degree-day factor or to add other input data, leading to a gradual transition to the energy balance models [e.g., Zuzel and Cox, 1975; Obled and Rosse, 1975; Kustas et al., 1994; Pellicciotti et al., 2005].

[5] Degree-day models have been applied in various climates; for instance in the Alps [Braun and Renner, 1992], Greenland [Braithwaite, 1995], Scandinavia [Kuusisto, 1980; Hock, 1999], the Himalayas [Singh and Kumar, 1996], or New Zealand [Woo and Fitzharris, 2001]. They have been used to investigate the sensitivity of glaciers to climate change distributed worldwide [Laumann and Reeh, 1993; Johanneson et al., 1995; Braithwaite and Zhang, 1999; De Woul and Hock, 2005]. However, few studies have investigated the physical causes of the good correlation between air temperature and ice melt. Paradoxically, net radiation generally is the greater incoming energy flux but is poorly correlated to air temperature. Hoinkes [1955] considered that temperature is a radiation index and is linked to the precipitation phase. Kuhn [1993] noted that temperature, like melting, results from all energy fluxes. The statistical analysis of Braithwaite [1981] on four glaciers of the Canadian Arctic concluded that the melting is correlated to the temperature through the sensible heat flux: although net radiation is the largest source of energy, the sensible heat flux is more variable and better correlated to temperature. According to Ohmura [2001], temperature is correlated to melting through the long-wave irradiance, which is the largest incoming energy flux. The long-wave irradiance mainly comes from the near-surface layer of the atmosphere, whose temperature is well correlated to the temperature measured at screen level.

[6] These analyses may be biased toward climatic conditions of well-documented glaciers in the mid and high latitudes. At low latitudes, empirical models, similar to degree-day approaches, have been used to simulate the mass balance without detailed examination of the hypotheses supporting the model [e.g., Hostetler and Clark, 2000; Kull and Grosjean, 2000; Pouyaud et al., 2005]. These hypotheses must be known and tested when the model is used outside the calibration experiment such as in different climatic areas or for mass balance forecasting or hindcasting. The analysis of Braithwaite [1981] was conducted in a single climatic area and Ohmura [2001] did not compare his hypotheses to correlations between glacier melting and temperature.

[7] The purpose of this study is to investigate the physical basis of temperature-index models for three glaciers in highly contrasting climates: Zongo $\left(16^{\circ} \mathrm{S}\right.$, Bolivian outer tropics), St Sorlin $\left(45^{\circ} \mathrm{N}\right.$, French Alps) and Storglaciären $\left(67^{\circ} \mathrm{N}\right.$, northern Sweden). On the basis of half-hourly data collected on the glaciers, the energy balance was computed during melt seasons and all energy balance components were correlated with each other and with air temperature on and outside the glacier, at the daily time scale. The magnitude and variability of each energy flux were examined and their contribution to the correlation between air temperature and melt energy was assessed. The analysis was compared to the results from Antizana Glacier in the Ecuadorian inner tropics and four glaciers in the Canadian Arctic. The correlations at the yearly time scale between mass balance, temperature, melt, and precipitations were briefly examined on Zongo Glacier. The potential influence of measurement errors and spurious self-correlations is also discussed.

\section{Study Sites and Field Data}

[8] Table 1 summarizes the characteristics of the three study sites. The Zongo Glacier lies in the outer tropics, characterized by a marked seasonality of precipitation and cloud cover with a single wet season in austral summer and a pronounced dry season in winter [Wagnon et al., 1999; Kaser, 2001]. St Sorlin is a valley glacier with a midlatitude temperate climate, located in the Western part of the French Alps (Grandes Rousses massif). Storglaciären is a polythermal glacier of Swedish Lapland in a sub-arctic climate with frequent cyclonic activity in summer.

[9] On each glacier, automatic weather stations were operated in the ablation area for at least one melt season recording 30-min averages of wind speed, air temperature and relative humidity, and upward and downward shortwave and long-wave radiation fluxes. The instrument heights varied between 1.0 to $1.5 \mathrm{~m}$, depending on the glacier experiment, and were regularly adjusted for ablation. Air temperature was also recorded in the vicinity but outside the thermal influence of the glacier (Table 1). On St Sorlin glacier, the turbulent fluxes of sensible and latent heat were measured with an eddy covariance station at proximity of the automatic weather station. A Campbell CSAT-3 sonic anemometer and a LI-COR LI-7500 infrared gas analyzer were installed at $2 \mathrm{~m}$ above the glacier surface. A Campbell CR1000 data logger recorded the wind, temperature and water vapor data at the $20 \mathrm{~Hz}$ frequency. The eddy covari- 
ance data were processed with the EdiRe software (R. Clement, University of Edinburgh); including despiking, double rotation, cross-correlation for derivation of time lag between the sonic anemometer and the gas analyzer, spectral corrections and Webb corrections.

[10] The site description and measurement programs are detailed in Sicart et al. [2005], Six et al. [2008] and Jonsell et al. [2003], for Zongo, St Sorlin and Storglaciären, respectively. On each site, the study period was characterized by surface temperatures at or close to the melting point and high melt rates.

\section{Methods}

[11] At each site, the surface energy balance (SEB) was calculated as:

$$
S E B=R+H+L E
$$

where $R$ is the net radiation and $H$ and $L E$ are the turbulent fluxes of sensible and latent heat, respectively. The heat advected by precipitation is small enough to be neglected. The term $S E B$ represents the sum of change in heat content in a control volume and the energy used for melting (positive) or freezing (negative). The fluxes are expressed in $\mathrm{W} \mathrm{m} \mathrm{m}^{-2}$ and are counted as positive if they provide energy to the control volume. The net radiation can be written as:

$$
R=S \downarrow-S \uparrow+L \downarrow-L \uparrow=S \downarrow(1-\alpha)+L \downarrow \varepsilon-\varepsilon \sigma T_{s}^{4}
$$

where $S \downarrow$ is the short-wave irradiance or global radiation, $S \uparrow$ is the reflected short-wave radiation $(S=S \downarrow-S \uparrow$ is the net short-wave radiation), $L \downarrow$ and $L \uparrow$ are the long-wave irradiance and emittance, respectively $(L=L \downarrow-L \uparrow$ is the net long-wave radiation). $\alpha$ is the surface albedo, $\varepsilon$ is the long-wave emissivity of ice, $\sigma=5.6710^{-8} \mathrm{~W} \mathrm{~m}^{-2} \mathrm{~K}^{-4}$ is the Stefan-Boltzmann constant, and $T_{s}$ is the surface temperature. Ice is assumed to be a full emitter $(\varepsilon=1)$, so that the reflection of long-wave radiation is neglected $\left(\alpha_{\text {long-wave }}=1-\varepsilon\right)$. The radiation fluxes were taken from the measurements. The turbulent fluxes were calculated with the bulk aerodynamic method, including stability correction calculated from the Businger-Dyer relations for the MoninObukhov length [e.g., Brutsaert, 1982]. The surface temperature was derived from the measurement of $L \uparrow$. The roughness lengths for momentum $z_{0}$, temperature $z_{0 T}$ and humidity $\mathrm{z}_{0 \mathrm{q}}$ were assumed equal to each other and set to $5 \mathrm{~mm}$ and $10 \mathrm{~mm}$ on Zongo and St Sorlin, respectively. On Storglaciären, we assumed $\mathrm{z}_{0}=10 \mathrm{~mm}$ and $\mathrm{z}_{0 \mathrm{~T}}=\mathrm{z}_{0 \mathrm{q}}=$ $0.1 \mathrm{~mm}$ [Hock and Holmgren, 2005].

[12] Computations were made with 30-min time steps and daily means were compiled. The energy balance calculations were validated against stake or ultrasonic depth gauge measurements in Sicart et al. [2005], Six et al. [2008] and Kramer [2001] for Zongo, St Sorlin and Storglaciären, respectively. Summer energy fluxes on St Sorlin and Storglaciären were compared to the wet season on Zongo Glacier, which is a period of steady melting conditions in the ablation area (austral summer). Assuming the subsurface ice heat flux was negligible, $S E B$ corresponded to the melting rate. Storglaciären is a polythermal glacier, but in summer only a few percent of $S E B$ is used for heating the subsurface ice [Hock and Holmgren, 2005].
[13] The daily energy fluxes were correlated with each other and with air temperature measured on $\left(T_{\text {glacier }}\right)$ and outside $\left(T_{\text {out }}\right)$ the glaciers. Then the contribution of each energy flux to the correlation between air temperature and $S E B$ was investigated. Following Braithwaite [1981], the linear correlation between air temperature and energy balance was written as the weighted sum of the correlations between the individual energy flux and temperature:

$$
r(T, S E B)=\sum_{i} \frac{\sigma_{x i}}{\sigma_{S E B}} r\left(T, x_{i}\right)
$$

where $\mathrm{r}\left(T, x_{i}\right)$ is the correlation coefficient between temperature and flux $x_{i}$, and $\sigma_{S E B}$ and $\sigma_{x i}$ are the standard deviations of the fluxes. Since $R=S+L$, two summations will be used: $x_{i}=H, L E, R$ and $x_{i}=H, L E, S, L$.

\section{Results}

\subsection{Magnitude and Variability of the Energy Fluxes}

[14] Tables 2-4 show the average and standard deviation of the energy fluxes and the correlation matrix of the fluxes and air temperature in each glacier. Figures 1-3 show the daily variations in energy fluxes, air temperature and albedo throughout the melting periods. Results are only shown here for one of the two melt seasons analyzed for Zongo Glacier and Storglaciären (Table 1), because both seasons yielded similar results.

[15] During the periods studied and on the three sites, the glacier emission in long-wave radiation _the largest sink of energy _ was constantly close to $316 \mathrm{~W} \mathrm{~m}^{-2}$, corresponding to the emission of ice at the melting point. Thus the longwave irradiance controlled the variations of $L\left(\sigma_{L \downarrow} \approx \sigma_{L}\right.$ and $\mathrm{r}(L \downarrow, L) \approx 1$; Tables 2-4). On each site, the long-wave irradiance was the largest source of energy, exceeding the short-wave irradiance, but its range of variation remained small $\left(\sigma_{L \downarrow}<30 \mathrm{~W} \mathrm{~m}^{-2}\right.$; Tables 2-4).

[16] The net short-wave radiation generally was the second largest energy gain after $L \downarrow$. On Zongo and St Sorlin, $S$ varied greatly $\left(\sigma_{S}=50-70 \mathrm{~W} \mathrm{~m}^{-2}\right)$ and closely matched the sum of the energy fluxes (Tables 2 and 3; Figures 1 and $2)$. On Storglaciären, the net short-wave radiation was smaller and less variable $\left(\sigma_{S}=30-40 \mathrm{~W} \mathrm{~m}^{-2}\right.$; Table 4; Figure 3).

[17] Because of air predominantly at positive temperature overlying a glacier surface at $0^{\circ} \mathrm{C}, H$ was a gain in energy: small on Zongo, but more pronounced on St Sorlin and Storglaciären (Figures 1-3). On Zongo and to a lesser extent on St Sorlin, $L E$ was a sink of energy (sublimation), canceling out most of the gains in $H$. On Storglaciären, $L E$ generally was positive (condensation), representing a significant gain in energy over both summers studied. The sum of turbulent fluxes on Storglaciären supplied almost the same amount of energy as the radiation fluxes (Table 4).

\subsection{Correlations Between Energy Fluxes}

[18] On the three glaciers, the turbulent fluxes were very poorly correlated to net radiation. Because of the wind control on turbulence, the fluxes $H$ and $L E$ were significantly correlated (or anti-correlated) to each other (Tables 2-4).

[19] On Zongo during the wet seasons 1997-1998 and 1999-2000, net radiation represented $85-90 \%$ of the energy gains, while the sum of turbulent fluxes remained 
Table 2. Correlation Coefficients Between Daily Energy Fluxes and Air Temperature on $\left(T_{\text {glacier }}\right)$ and Outside $\left(T_{\text {out }}\right)$ the Glacier at Zongo, From November 1 to December 21, 1999 (Wet Season, $n=51)^{\mathrm{a}}$

\begin{tabular}{|c|c|c|c|c|c|c|c|c|c|c|}
\hline & $S E B$ & $R$ & $H$ & $L E$ & $S \downarrow$ & $S$ & $L \downarrow$ & $L$ & $T_{\text {glacier }}$ & $T_{\text {out }}$ \\
\hline Average $^{\mathrm{b}}$ & 62 & 64 & 15 & -17 & 214 & 103 & 269 & -39 & 0.2 & 2.0 \\
\hline$\sigma^{\mathrm{b}}$ & 47 & 46 & 15 & 21 & 69 & 60 & 25 & 23 & 1.1 & 1.2 \\
\hline$r$ & $S E B$ & $R$ & $H$ & $L E$ & $S \downarrow$ & $S$ & $L \downarrow$ & $L$ & $T_{\text {glacier }}$ & $T_{\text {out }}$ \\
\hline$S E B$ & 1.00 & 0.96 & 0.06 & 0.06 & 0.37 & 0.89 & -0.33 & -0.38 & $\mathbf{0 . 3 8}$ & 0.51 \\
\hline$R$ & & 1.00 & 0.11 & -0.14 & 0.48 & 0.94 & -0.38 & -0.43 & 0.23 & 0.42 \\
\hline$H$ & & & 1.00 & -0.81 & 0.67 & 0.36 & -0.72 & -0.73 & 0.50 & 0.54 \\
\hline$L E$ & & & & 1.00 & -0.71 & -0.34 & 0.61 & 0.61 & -0.04 & -0.18 \\
\hline$S \downarrow$ & & & & & 1.00 & 0.63 & -0.65 & -0.68 & 0.33 & 0.48 \\
\hline$S$ & & & & & & 1.00 & -0.68 & -0.72 & 0.35 & 0.56 \\
\hline$L \downarrow$ & & & & & & & 1.00 & 0.99 & -0.38 & -0.56 \\
\hline$L$ & & & & & & & & 1.00 & -0.44 & -0.61 \\
\hline$T_{\text {glacier }}$ & & & & & & & & & 1.00 & 0.88 \\
\hline$T_{\text {out }}$ & & & & & & & & & & 1.00 \\
\hline
\end{tabular}

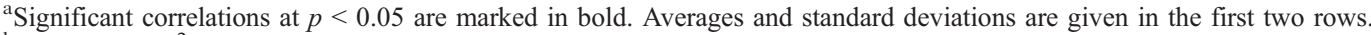

${ }^{\mathrm{b}}$ Flux in $\mathrm{W} \mathrm{m}{ }^{-2}$, temperature in ${ }^{\circ} \mathrm{C}$.

very small. The variations of $R$ controlled the variations of the energy balance almost entirely $\left(\mathrm{r}^{2}(R, S E B) \approx 0.9\right)$, essentially through net short-wave radiation $\left(\mathrm{r}^{2}(S, S E B) \approx\right.$ 0.8 ), whereas $S E B$ was very poorly correlated to the turbulent fluxes and to the long-wave irradiance $\left(\mathrm{r}^{2}<0.2\right.$; Table 2). On St Sorlin, the relative contribution of $R$ to the energy balance was slightly smaller than on Zongo (around $80 \%$ of the gains) because of a higher value of $H$ (Table 3 ). As on Zongo, the variations of the energy balance were mainly controlled by $R$ through net short-wave radiation $\left(\mathrm{r}^{2}(S, S E B) \approx 0.75\right)$.

[20] On Storglaciären, given the larger $H$ and positive $L E$, the distribution of the energy sources was better balanced: $40 \%$ [55\%], 49\% [33\%], and 11\% [13\%] of $S E B$ for $R, H$, and $L E$, respectively, in summer 1999 [summer 2000]. $H$ accounted for approximately $70 \%$ of the variance of $S E B$, followed by $L E$ and $R\left(\mathrm{r}^{2}(L E, S E B) \approx 0.4 ; \mathrm{r}^{2}(R, S E B) \approx 0.3\right.$; Table 4). On each glacier, the long-wave irradiance was very poorly (or not significantly) negatively correlated to melt energy $\left(\mathrm{r}^{2}(L \downarrow, S E B)<0.15\right)$.

\subsection{Correlations With Temperature}

[21] The air temperatures on and outside the glacier were strongly correlated to each other (Tables 2-4). The averages and standard deviations of $T_{\text {out }}$ were somewhat higher than those of $T_{\text {glacier, }}$ probably because of the thermal dampening effect of the ice whose maximal temperature is bounded at $0^{\circ} \mathrm{C} . T_{\text {glacier }}$ and $T_{\text {out }}$ were similarly correlated to the energy fluxes at the three glaciers (Tables 2-5).

[22] The temperature standard deviations were much smaller on Zongo than on Sorlin and Storglaciären. The positive correlations between the energy balance and the air temperature were small on Zongo $\left(\mathrm{r}^{2}(T, S E B)<0.30\right)$, moderate on Storglaciären $\left(\mathrm{r}^{2}(T, S E B) \approx 0.4-0.6\right)$, and high on St Sorlin $\left(\mathrm{r}^{2}(T, S E B) \approx 0.65\right.$; Tables $\left.2-5\right)$.

[23] Air temperature was very poorly (or not significantly) correlated with $R$ and with $S$ on Zongo and Storglaciären (Tables 2 and 4). In contrast, $T$ on St Sorlin was strongly correlated to net radiation, mainly through short-wave radiation $(\mathrm{r}(T, R) \approx \mathrm{r}(T, \mathrm{~S}) \approx 0.7$; Table 3$)$. The correlations between temperature and long-wave irradiance were small: negative on Zongo and St Sorlin, and positive (but not significant) on Storglaciären.

[24] The correlations between temperature and the turbulent fluxes were small on Zongo and St Sorlin $(\mathrm{r}(H, T)<$ $0.55, \mathrm{r}(L E, T)$ not significant), whereas the turbulent fluxes on Storglaciären correlated better with $T$ (r up to 0.6).

\subsection{Contribution of Each Energy Flux to the Correlation Between Melt Energy and Air Temperature}

[25] Table 5 shows the percentage contributions of each energy flux to the correlation between melt energy and air

Table 3. Correlation Coefficients Between Daily Energy Fluxes and Air Temperature on $\left(T_{\text {glacier }}\right)$ and Outside $\left(T_{\text {out }}\right)$ the Glacier at St Sorlin, From July 9 to August 27, $2006(n=50)^{\mathrm{a}}$

\begin{tabular}{|c|c|c|c|c|c|c|c|c|c|c|}
\hline & $S E B$ & $R$ & $H$ & $L E$ & $S \downarrow$ & $S$ & $L \downarrow$ & $L$ & $T_{\text {glacier }}$ & $T_{\text {out }}$ \\
\hline Average $^{b}$ & 152 & 127 & 33 & -8 & 233 & 161 & 283 & -33 & 5.4 & 6.2 \\
\hline$\sigma^{\mathrm{b}}$ & 70 & 55 & 30 & 20 & 69 & 68 & 23 & 22 & 3.3 & 4.0 \\
\hline$r$ & $S E B$ & $R$ & $H$ & $L E$ & $S \downarrow$ & $S$ & $L \downarrow$ & $L$ & $T_{\text {glacier }}$ & $T_{\text {out }}$ \\
\hline$S E B$ & 1.00 & 0.95 & 0.48 & 0.18 & 0.60 & 0.88 & -0.20 & -0.33 & 0.80 & 0.80 \\
\hline$R$ & & 1.00 & 0.26 & 0.17 & 0.74 & 0.96 & -0.32 & -0.44 & 0.71 & 0.71 \\
\hline$H$ & & & 1.00 & -0.55 & 0.16 & 0.24 & -0.05 & -0.10 & 0.41 & 0.40 \\
\hline$L E$ & & & & 1.00 & -0.19 & 0.06 & 0.26 & 0.22 & 0.23 & 0.24 \\
\hline$S \downarrow$ & & & & & 1.00 & 0.86 & -0.74 & -0.79 & 0.44 & 0.44 \\
\hline$S$ & & & & & & 1.00 & -0.58 & -0.68 & 0.71 & 0.71 \\
\hline$L \downarrow$ & & & & & & & 1.00 & 0.99 & -0.28 & -0.29 \\
\hline$L$ & & & & & & & & 1.00 & -0.41 & -0.42 \\
\hline$T_{\text {glacier }}$ & & & & & & & & & 1.00 & 1.00 \\
\hline$T_{\text {out }}$ & & & & & & & & & & 1.00 \\
\hline
\end{tabular}

${ }^{\text {a }}$ Significant correlations at $p<0.05$ are marked in bold. Averages and standard deviations are given in the first two rows.

${ }^{\mathrm{b}}$ Flux in $\mathrm{W} \mathrm{m}{ }^{-2}$, temperature in ${ }^{\circ} \mathrm{C}$. 

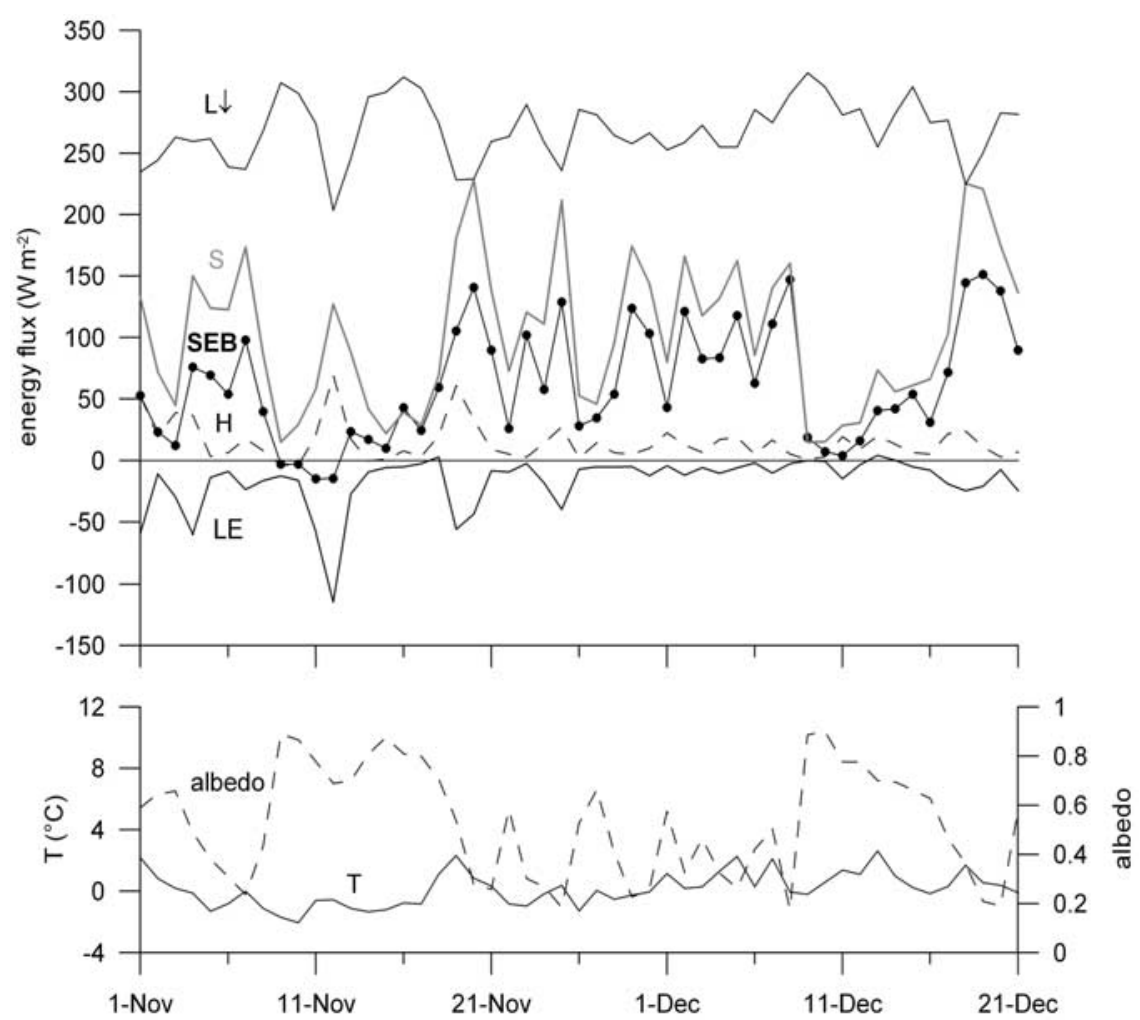

Figure 1. Zongo glacier, daily energy fluxes from 1 November 1999 to 21 December 1999. Top: incoming long-wave radiation $(L \downarrow)$, net short-wave radiation $(S)$, turbulent fluxes of sensible $(H)$ and latent heat $(L E)$, and sum of the energy fluxes $(S E B)$. Bottom: air temperature $(T)$ and albedo.
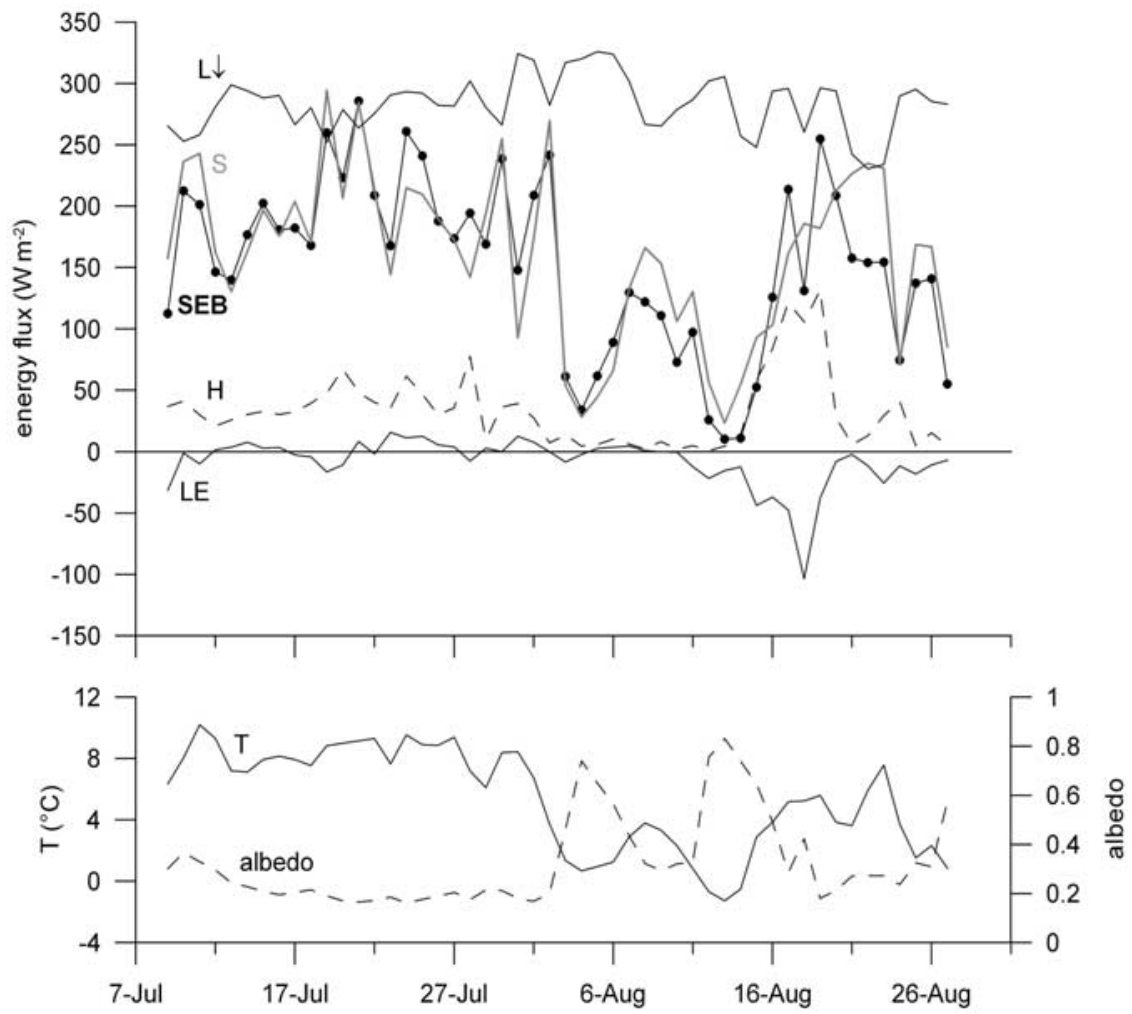

Figure 2. St Sorlin glacier, daily energy fluxes from 9 July to 27 August 2006. Top: incoming longwave radiation $(L \downarrow)$, net short-wave radiation $(S)$, turbulent fluxes of sensible $(H)$ and latent heat $(L E)$, and sum of the energy fluxes $(S E B)$. Bottom: air temperature $(T)$ and albedo. 


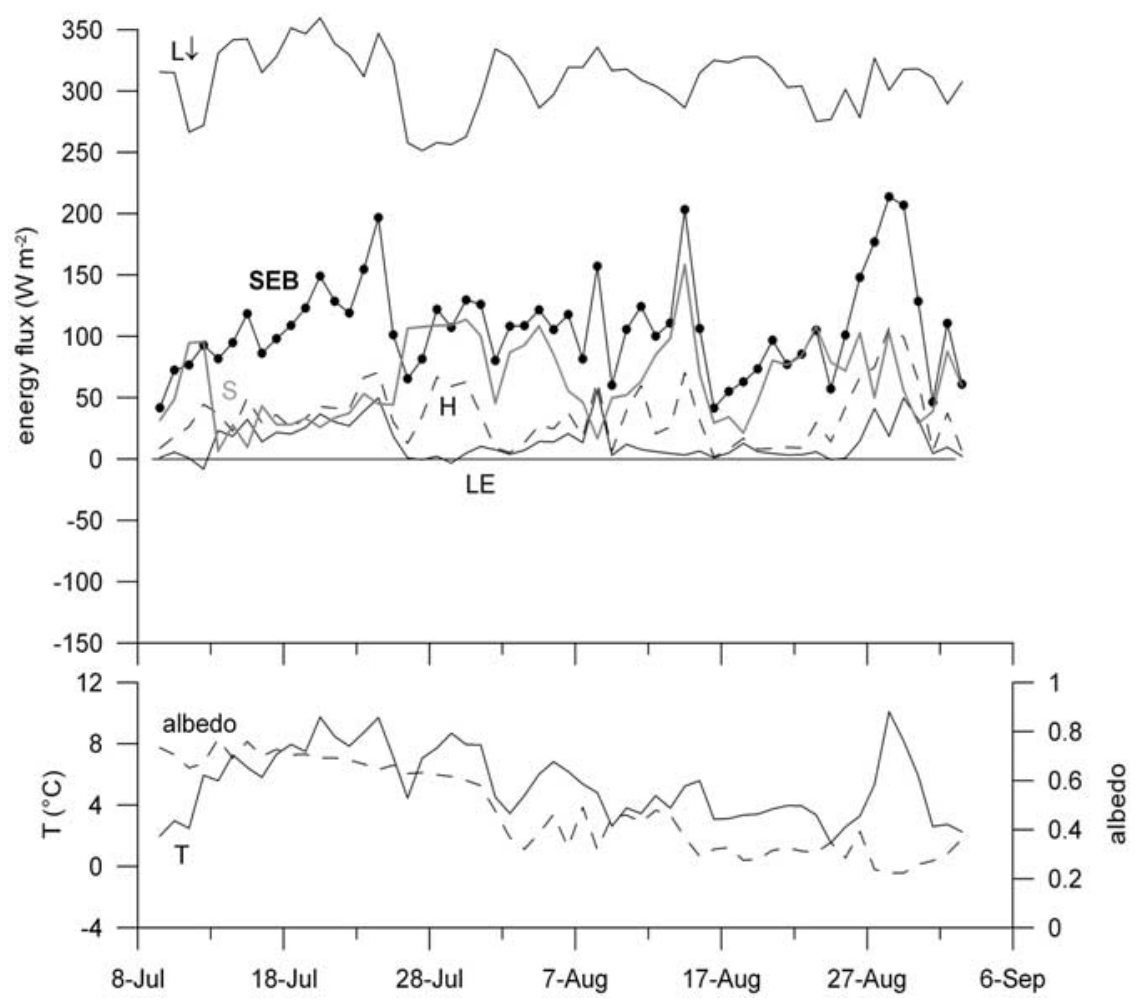

Figure 3. Storglaciären, daily energy fluxes from 9 July to 2 September 2000. Top: incoming longwave radiation $(L \downarrow)$, net short-wave radiation $(S)$, turbulent fluxes of sensible $(H)$ and latent heat $(L E)$, and sum of the energy fluxes $(S E B)$. Lower panel: air temperature $(T)$ and albedo.

temperature (equation (3)). The contribution of each flux depends on its variance and its correlation with temperature.

[26] Two additional sites were considered: (1) calculations on the Antizana glacier $\left(0^{\circ} 28^{\prime}\right)$ in the humid inner tropics from data collected at $4890 \mathrm{~m}$ asl by Favier et al. [2004] and (2) results published by Braithwaite [1981] on four glaciers in the Arctic. On Antizana, the magnitude, variability, and correlations of the energy fluxes were very similar to those on Zongo. In particular, the energy balance was poorly correlated to the air temperature (Table 5). The relative contributions of each flux to $r(T, S E B)$ were also similar: $r(T, S E B)$ was largely dominated by the radiation flux, essentially through short-wave radiation (Table 5). The contributions of $H(\mathrm{r}(H, T)>0)$ and $L E(\mathrm{r}(L E, T)<0)$ to $\mathrm{r}(T, S E B)$ tended to cancel each other out.

[27] On St Sorlin, radiation prevailed in the high correlation between the energy balance and temperature $\left(\mathrm{r}^{2}(T\right.$, $S E B)=0.64)$. The contribution of $H$ was not greater than at lower latitudes but the contribution of $L E$ was positive, so that the positive contribution of $L E+H$ was slightly greater. On Storglaciären and in the Canadian Arctic, the contribution of $H$ prevailed in the correlations between the energy balance and temperature (Table 5). $L E$ was positively correlated to $T$ and its contribution to $\mathrm{r}(T, S E B)$ was substantial second behind $H_{-}$, so that the turbulent fluxes largely prevailed in the correlations between $T$ and $S E B$ (Table 5).

Table 4. Correlation Coefficients Between Daily Energy Fluxes and Air Temperature on ( $\left.T_{\text {glacier }}\right)$ and Outside ( $\left.T_{\text {out }}\right)$ the Glacier at Storglaciären, From July 9 to September 2, $2000(n=57)^{\mathrm{a}}$

\begin{tabular}{|c|c|c|c|c|c|c|c|c|c|c|}
\hline & $S E B$ & $R$ & $H$ & $L E$ & $S \downarrow$ & $S$ & $L \downarrow$ & $L$ & $T_{\text {glacier }}$ & $T_{\text {out }}$ \\
\hline Average $^{b}$ & 108 & 59 & 35 & 14 & 133 & 64 & 309 & -6 & 5.4 & 7.6 \\
\hline$\sigma^{\mathrm{b}}$ & 40 & 19 & 25 & 15 & 75 & 33 & 26 & 25 & 2.3 & 2.6 \\
\hline$r$ & $S E B$ & $R$ & $H$ & $L E$ & $S \downarrow$ & $S$ & $L \downarrow$ & $L$ & $T_{\text {glacier }}$ & $T_{\text {out }}$ \\
\hline$S E B$ & 1.00 & 0.50 & 0.88 & 0.64 & 0.09 & 0.22 & 0.09 & 0.08 & $\mathbf{0 . 6 3}$ & 0.59 \\
\hline$R$ & & 1.00 & 0.14 & -0.13 & 0.34 & 0.66 & -0.12 & -0.13 & 0.15 & 0.16 \\
\hline$H$ & & & 1.00 & 0.55 & 0.16 & 0.17 & -0.11 & -0.11 & 0.60 & 0.58 \\
\hline$L E$ & & & & 1.00 & -0.46 & -0.52 & 0.59 & 0.59 & 0.54 & 0.46 \\
\hline$S$ & & & & & 1.00 & 0.80 & -0.81 & -0.81 & 0.20 & 0.34 \\
\hline$S$ & & & & & & 1.00 & -0.83 & -0.83 & -0.04 & 0.09 \\
\hline$L \downarrow$ & & & & & & & 1.00 & 1.00 & 0.16 & 0.01 \\
\hline$L$ & & & & & & & & 1.00 & 0.16 & 0.00 \\
\hline$T_{\text {glacier }}$ & & & & & & & & & 1.00 & 0.95 \\
\hline$T_{\text {out }}$ & & & & & & & & & & 1.00 \\
\hline
\end{tabular}

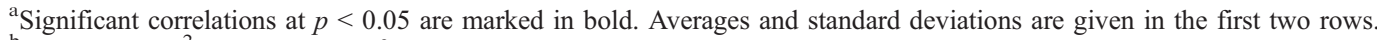

${ }^{\mathrm{b}}$ Flux in $\mathrm{W} \mathrm{m}^{-2}$, temperature in ${ }^{\circ} \mathrm{C}$. 
Table 5. Contribution of Each Energy Flux (\%) to the Correlation Between Melt Energy (SEB) and Air Temperature ${ }^{\mathrm{a}}$

\begin{tabular}{|c|c|c|c|c|c|c|c|c|c|}
\hline & $n^{\mathrm{b}}$ & $T$ & $r^{2}\left(T_{\text {glacier }}, T_{\text {out }}\right)$ & $r^{2}(T, S E B)$ & $\begin{array}{c}R \\
(\%)\end{array}$ & $\begin{array}{c}H \\
(\%)\end{array}$ & $\begin{array}{r}L E \\
(\%) \\
\end{array}$ & $\begin{array}{c}S \\
(\%) \\
\end{array}$ & $\begin{array}{c}L \\
(\%) \\
\end{array}$ \\
\hline Zongo wet season $97-98$ & 119 & $T_{\text {glacier }}$ & 0.75 & 0.20 & 89 & 11 & 0 & & \\
\hline \multirow[t]{2}{*}{ Zongo wet season $99-00$} & 51 & $T_{\text {glacier }}$ & \multirow[t]{2}{*}{0.77} & 0.14 & 61 & 43 & -4 & 119 & -58 \\
\hline & 51 & $T_{\text {out }}$ & & 0.26 & 82 & 34 & -16 & 142 & -60 \\
\hline Antizana, Ecuador $02-03^{\mathrm{c}}$ & 181 & $T_{\text {glacier }}$ & \multirow{3}{*}{0.99} & 0.15 & 93 & 43 & -36 & 182 & -89 \\
\hline \multirow{2}{*}{ St sorlin 2006} & 50 & $T_{\text {glacier }}$ & & 0.64 & 70 & 22 & 8 & 86 & -16 \\
\hline & 50 & $T_{\text {out }}$ & & 0.64 & 70 & 22 & 8 & 87 & -17 \\
\hline St sorlin 2006 , neutral ${ }^{\mathrm{d}}$ & 50 & $T_{\text {glacier }}$ & & 0.76 & 52 & 41 & 7 & 64 & -12 \\
\hline St sorlin 2006 , eddy covar. ${ }^{\mathrm{e}}$ & 43 & $T_{\text {glacier }}$ & \multirow{7}{*}{0.90} & 0.48 & 70 & 19 & 11 & 82 & -12 \\
\hline Storglaciären 1999 & 32 & $T_{\text {glacier }}$ & & 0.57 & 26 & 45 & 29 & 29 & -3 \\
\hline Storglaciären 1999, neutral ${ }^{\mathrm{d}}$ & 32 & $T_{\text {glacier }}^{\text {suct }}$ & & 0.57 & 22 & 50 & 28 & 25 & -3 \\
\hline \multirow[t]{2}{*}{ Storglaciären 2000} & 57 & $T_{\text {glacier }}$ & & 0.40 & 11 & 58 & 31 & -5 & 16 \\
\hline & 57 & $T_{\text {out }}$ & & 0.35 & 12 & 60 & 28 & 12 & 0 \\
\hline Storglaciären 2000, neutral ${ }^{\mathrm{d}}$ & 57 & $T_{\text {glacier }}$ & & 0.40 & 8 & 61 & 31 & -4 & 12 \\
\hline Canadian $\operatorname{Arctic}^{\mathrm{f}}$ & 113 & $T_{\text {glacier }}$ & & 0.59 & 9 & 68 & 23 & & \\
\hline
\end{tabular}

${ }^{a}$ Two summations of equation (3) are used: both contribution sums $(H, L E, R)$ and $(H, L E, S, L)$ equal $100 \%$ each (cf. text). The largest contributor within $(R, H, L E)$ is highlighted in bold.

${ }^{\mathrm{b}}$ Number of days.

${ }^{\mathrm{c}}$ Data from Favier et al. [2004], September 2002-March 2003, $4890 \mathrm{~m}$ asl.

${ }^{\mathrm{d}} H$ and $L E$ calculated with the bulk method without stability correction.

${ }^{\mathrm{e}} H$ and $L E$ measured with the eddy covariance method.

f Braithwaite [1981], averages of four glaciers.

\subsection{Yearly Mass Balance and Temperature on Zongo Glacier}

[28] The Zongo Glacier is part of the $3-\mathrm{km}^{2}$ drainage basin of the limnimetric station at $4830 \mathrm{~m}$ asl $(73 \%$ glacierized). The mass balance has been assessed using glaciological and hydrological methods since 1992. A network of seven cumulative rain gauges measures the precipitation in the basin. Glacier melt was calculated by subtracting the fraction of discharge coming from the unglaciarized surface from the measured discharge at the basin outlet. The unglaciarized fraction was derived from precipitations and a fixed runoff coefficient [Sicart et al., 2007]. At the annual time scale, the average net mass balance of Zongo Glacier was well correlated to the mean air temperature $\left(T_{\text {out }}\right)$ over the period 1996-2006 $\left(\mathrm{r}^{2}=0.76\right.$; Figure 4), but the data set is small. Melt and precipitation amounts each accounted for approximately $70 \%$ of the variability of the mass balance (Figure 4).

[29] Precipitation and temperature were not strongly correlated to each other $\left(r^{2}<0.5\right)$ and melt was poorly correlated to temperature $\left(r^{2}=0.3\right)$. On Zongo Glacier, an El Niño year is characterized by high temperature and low precipitation, resulting in high melt rates and a very negative mass balance [Wagnon et al., 2001]. Since the $1998 \mathrm{El}$ Niño year would artificially draw the correlations, this year was excluded from the correlations given in the plots. Figure 4 confirms that it is more the distribution of precipitations throughout the year _the wet season is delayed _ than its total amount that characterizes an El Niño year.

\section{Discussion}

\subsection{Influence of the Measurement Errors on the Correlations}

[30] Random measurement errors decrease the correlations. Let $(x, y)$ be the true values, $\left(x^{\prime}, y^{\prime}\right)$ the observations, and $\left(x^{\prime \prime}, y^{\prime \prime}\right)$ the measurement errors, we have: $x^{\prime}=x+x^{\prime \prime}$ and $y^{\prime}=y+y^{\prime \prime}$. Assuming the measurement errors are independent of each other and independent of the true values, the relation between the true coefficient of correlation $(r)$ related to the true variables and the coefficient of correlation $\left(r^{\prime}\right)$ related to the observations can be written as [Dagnelie, 1975]:

$$
r=\frac{r^{\prime}}{\sqrt{\left(1-\frac{\sigma_{x^{\prime \prime}}^{2}}{\sigma_{x^{\prime}}^{2}}\right)\left(1-\frac{\sigma_{y^{\prime \prime}}^{2}}{\sigma_{y^{\prime}}^{2}}\right)}}
$$

[31] Let us consider the correlation between air temperature and an energy flux $y$. The temperature measurement is quite reliable and it can be assumed that the variability of the error is much smaller than the measured variability $\left(\sigma_{T^{\prime \prime}} \ll\right.$ $\sigma_{T^{\prime}}$ ). With $Y=\sigma_{y^{\prime \prime}} / \sigma_{y^{\prime}}$, equation (4) can be written as:

$$
\frac{r^{\prime}}{r}=\sqrt{1-Y^{2}}
$$

[32] Equation (5) describes a circle of unity radius (Figure 5) and the decrease in explained variance is parabolic $\left(\left(r^{\prime} / r\right)^{2}=1-Y^{2}\right)$. On glaciers, the radiation fluxes are generally directly measured and have a large variability, so that their errors probably do not alter the correlations much. However, the error on the turbulent fluxes can be large, significantly reducing the correlations. Considering that the variability of the error in $H$ reaches $50-60 \%$ of the variability of the observations, the correlations between $H$ and $T$ in Tables 2-4 may be underestimated by $10-20 \%$ (Figure 5). Thus the errors in the turbulent fluxes may cause an underestimation of their contribution to the correlation between melting rate and temperature (equation (3)).

[33] The hypothesis that the error is independent of the true value is questionable. For instance in cloudy weather, the intensity and variability of most energy fluxes are reduced and the errors can be large because of snowfalls or frost deposition on the sensors.

\subsection{Spurious Self-Correlations}

[34] Since the calculations of the turbulent fluxes over glaciers generally depend on the mean temperature, the 

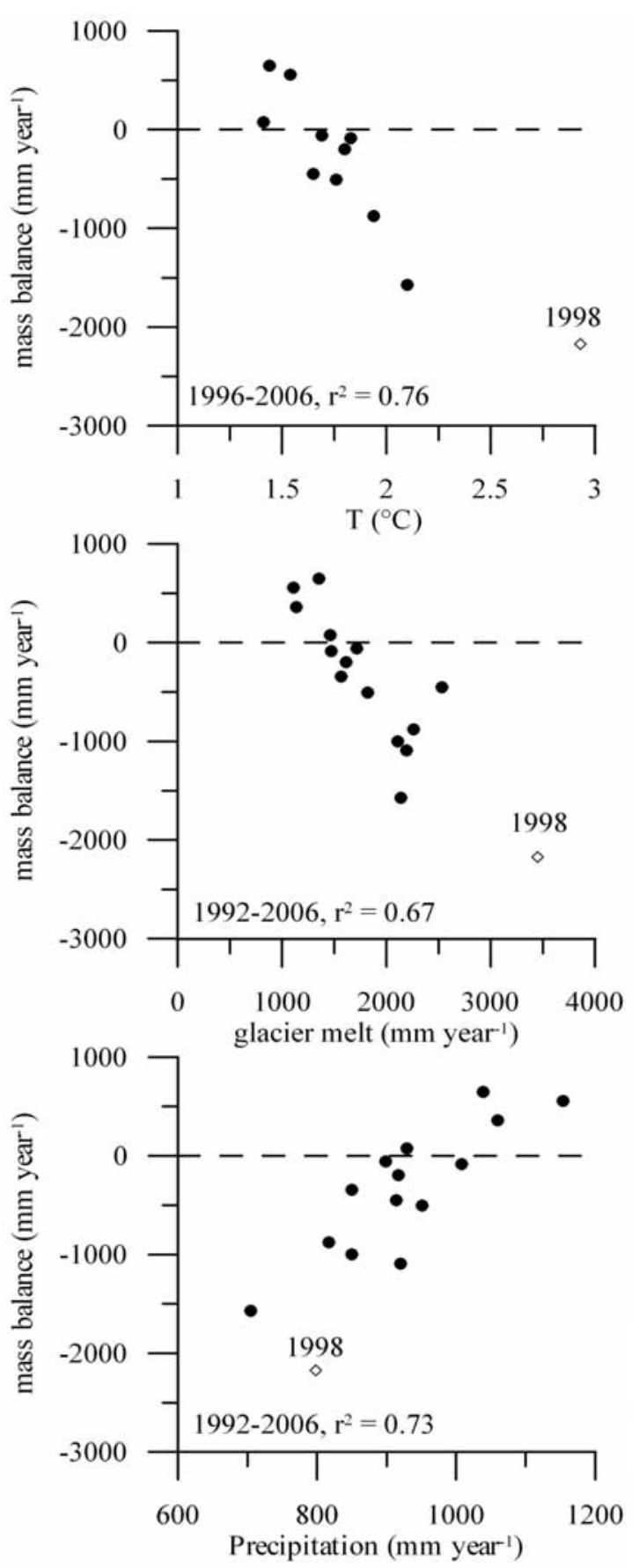

Figure 4. Annual mass balance versus temperature, melt and precipitation, Zongo Glacier. The hydrological year is counted from 1 September. The "El Niño" year 1998 is excluded from the correlations.

correlations of these fluxes with temperature may be spurious [e.g., Kenney, 1982]. If correction for air stability is ignored, $H$ is calculated from formulae such as:

$$
H=C u\left(T-T_{s}\right)
$$

where $u$ is the wind speed and $C$ depends on the roughness lengths, on air density and on the specific heat capacity of the air. Spurious self-correlations between $T$ and $H$ are very probable here: $T$ and $u$ are generally poorly correlated to each other and $T_{S}$ does not vary much on melting glaciers.

[35] Calculations on St Sorlin and Storglaciären show that the overestimation of the contribution of $H$ to $\mathrm{r}(T, S E B)$ caused by ignoring stability corrections can be large (10$20 \%$, "neutral" calculations in Table 5). The correlations between $H$ and $T$ were then totally spurious: the slopes were close to 1 and the spurious correlation coefficients calculated from the analytical formulae of Brett [2004] were very close to the coefficients resulting from the "neutral" calculations. On St Sorlin, the relative contribution of the "neutral" $H$ to the correlation of melt energy with temperature almost reaches the radiation contribution (Table 5). Given that Braithwaite [1981] did not include any air stability correction in the calculations of the turbulent fluxes, the relative contribution of $H$ may be largely overestimated in his study (Table 5).

[36] In static stability, the spurious self-correlations are difficult to evaluate because of the negative retroaction of air temperature on $H$. Air was moderately stable on Zongo and Storglaciären: the bulk Richardson number ranged from 0 to 0.1 for $50 \%$ of the hourly data. The correlation slopes were not related to the power of $T$ in the calculations of $H$, suggesting a small influence of spurious self-correlations [Kenney, 1982].

[37] Comparisons of $H$ with $T_{\text {out }}$ instead of $T_{\text {glacier }}$ would not avoid spurious self-correlations since $T_{\text {out }}$ was closely correlated to $T_{\text {glacier }}$ (Table 5). The direct measure of the turbulent fluxes with the eddy-covariance method is independent of the mean temperature measurement. Table 5 also shows the correlations of temperature with the turbulent fluxes measured with the eddy covariance method on St Sorlin glacier. The contribution of $H$ to the correlation between melt energy and temperature is slightly smaller and the contribution of $L E$ is slightly larger than the correlations with the turbulent fluxes derived from the bulk method with air stability correction. The differences are small and partly due to slight differences in measurement periods. The good agreement between two independent methods suggests that spurious self-correlations do not artificially increase much the correlations between air temperature and the bulk turbulent fluxes. However, the measurement period is short and more eddy covariance measurements are required.

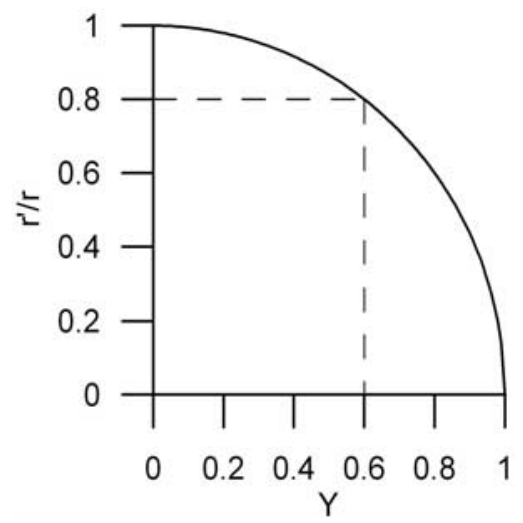

Figure 5. Relative decrease of the correlation coefficients $\left(r^{\prime} / r\right)$ versus the ratio of standard deviations of the measurement errors $(Y)$, equation (5). 


\subsection{Long-Wave Radiation}

[38] The emission in long-wave radiation concerns an infinitesimally thin layer, which does not store heat. Following Ohmura [2001], we consider the long-wave emittance as a passive flux, apart from the other energy fluxes. As a consequence, the long-wave irradiance is by far the largest source of melting energy before the net short-wave radiation and the turbulent fluxes in all the case studies from low to high latitudes (Tables 2-4). However, $L \downarrow$ did not vary much over the melting seasons and was poorly correlated to air temperature (standard deviations and correlations in Tables $2-4$ ). In the tropics and in the Alps, large $L \downarrow$ values generally were associated with reduced melting energy (Figures 1 and 2). On Storglaciären, the positive correlations of $L \downarrow$ with melting energy and with temperature were not significant (Figure 3; Table 4).

[39] Since the majority of the sky long-wave radiation received at the surface comes from the near-surface layer of the atmosphere, the clear-sky long-wave irradiance is positively correlated to air temperature. However, the higher the elevation, the smaller the thickness of the emitting atmosphere is and the larger the influence of cloud emission on $L \downarrow$. In high-altitude mountains, large long-wave irradiances are due to clouds that generally reduce the total melting energy. In the very high elevations of tropical glaciers, the long-wave irradiance is significantly negatively correlated to air temperature and to melting energy (Table 2). Similarly, cloud emissions control $L \downarrow$ in cold and dry climates [e.g., Sicart et al., 2006].

[40] Ohmura [2001] argued that the air temperature information is transferred to the surface mainly through long-wave atmospheric radiation. An argument was that $L \downarrow$ is the most important heat source for melt. This point is certainly true in most climates; however, it is not sufficient: (1) $L \downarrow$ has a low variability compared to the other energy fluxes and (2) $L \downarrow$ is poorly correlated to air temperature when cloud emissions dominate its variability, as in high mountains. Equation (3) results in small (and generally negative) contributions of the long-wave irradiance to the correlations between melting energy and air temperature in the three case studies (remembering that $\sigma_{L \downarrow} \approx \sigma_{L}$ and $\mathrm{r}(L \downarrow, L) \approx 1$; Table 5).

\subsection{Zongo Glacier}

[41] On the very high-altitude mountains from the inner humid to the outer tropics, radiation fluxes control the energy balance over the melt season. The turbulent heat fluxes are not substantial and the gains in sensible heat are mostly canceled out by the energy sink in sublimation because of very dry air at high altitudes. The turbulent sensible heat flux is small and does not vary much because (1) the $0^{\circ} \mathrm{C}$ isothermal elevation varies little over the year and air temperature remains low during the melt season (Figure 1; Table 2), (2) the light air at very high altitude carries less heat, and (3) wind is generally not strong. The long-wave irradiance is the main energy source but does not vary much during the melt season, whereas the net shortwave radiation, poorly correlated to temperature, controls the variations of the energy available for melting. On tropical glaciers, air temperature is a poor index of melting at short time steps.
[42] At the yearly time scale, air temperature is well correlated to the mass balance of Zongo Glacier $\left(r^{2} \approx\right.$ 0.75; Figure 4). Melt and precipitation each account for approximately two-thirds of mass balance variability. Air temperature is poorly correlated to the glacier melt, suggesting that temperature is linked to the mass balance through the ablation and the accumulation processes: clouds generally cause low temperatures. However, the data set is small (10 years) and longer periods are required to derive correlations suitable for mass balance forecasting or hind-casting.

\subsection{St Sorlin Glacier}

[43] The turbulent sensible heat flux is larger than on Zongo mainly because of higher air temperatures (Figure 2). However, the energy consumed by sublimation partly cancels out the energy gains in $H$ and the sum of the turbulent fluxes remains small on St Sorlin. The net shortwave radiation controls most of the variability of melting energy and is well correlated to the air temperature, resulting in good correlations of melting energy with air temperature at the daily time scale. The correlations between air temperature and net short-wave radiation may be linked to the advection of warm air coming from the valley floor, which is heated by short-wave radiation during the daytime. However, observations over longer periods are required.

[44] Pellicciotti et al. [2008] analyzed the melting processes at $3127 \mathrm{~m}$ asl in the ablation area of Juncal Norte Glacier in the Chilean sub-tropics. The sky remained cloudless throughout the melt season, the sky long-wave irradiance did not vary much, the air was warm $\left(8^{\circ} \mathrm{C}\right.$ on average) and dry, and melting was controlled by short-wave radiation. Energy lost in sublimation cancelled out most of the energy gains in sensible heat and the sum of turbulent fluxes remained small. As on St Sorlin, air temperature was well correlated to the melt energy through its good correlation to net short-wave radiation $\left(\mathrm{r}^{2}(S E B, S) \approx 0.85, n=63\right)$. Lang and Braun [1990] found a (slightly) better correlation of the daily melting on Aletsch Glacier with the air temperature measured in the valley $60 \mathrm{~km}$ from the glacier than with those measured on the mountain site near the glacier. The authors argued that air temperature in the valley was controlled by the radiation fluxes, which were the main energy sources of glacier melt, whereas the temperature on the "well exposed" mountain site was controlled by advection.

\subsection{Storglaciären}

[45] Only on Storglaciären did the contribution of the turbulent fluxes to the correlation between melt energy and temperature exceed the radiation contribution (Table 5). The importance of $H$ in controlling the melting energy on Storglaciären, compared to Zongo and St Sorlin, is evident in Figures 1-3. These results support the conclusions of Braithwaite [1981], who attributed the high correlation between temperature and melt rates to the sensible heat flux because of its large variability and its close correlation with temperature.

[46] The turbulent fluxes prevail in the correlations between melt energy and temperature on Storglaciären, and certainly on high-latitude glaciers of maritime climate, 
because (1) $S$ is small as a result of low sun elevation and high cloudiness associated with frequent cyclonic activity in summer, (2) $H$ is high because of high air temperature at low elevation, and (3) $L E$ is positive because of humid air. However, the relative importance of $H$ and $L E$ (quantified by the Bowen ratio) is generally not well known in bulk methods; e.g., the ratio of roughness lengths for temperature and humidity is not constrained on glaciers, and the default hypothesis often postulates equal lengths.

\subsection{Surface Albedo}

[47] On St Sorlin, the surface at the weather station remained snow-free over the study period except during a few snowfall events resulting from cyclonic activity causing cold weather (Figure 2). The new snow was shallow and rapidly melted after a few days. The albedo was low and temporarily increased during these cold events, reducing the melt energy (Figure 2). The changes in albedo from ice to snow contributed to the good correlations of air temperature with net short-wave radiation $(\mathrm{r}(T, S \downarrow)<\mathrm{r}(T, S))$, and thus with total melt energy (Table 3).

[48] On Zongo and Antizana, light snowfalls are frequent during the melt season and the surface continuously alternates between ice and thin snow layers that rapidly melt away. Solid precipitations in the wet season are not associated with cold storms, but are of convective nature, linked to the thermally forced circulation, and occur at rather high temperatures [Sicart et al., 2002]. Figure 1 shows that snowfalls were not associated with a large drop in air temperature, which remained close to $0^{\circ} \mathrm{C}$ during the 1999 melt season. Thus the albedo variations due to alternation of snow and ice surfaces were poorly correlated to air temperature, contributing to the weak correlation of temperature with net short-wave radiation (Table 2). In August 2007, a 27-day period of ice melting, with no snowfall, was recorded on Zongo at $5050 \mathrm{~m}$ asl. As during the 1999 melt season, the variations in melt energy were controlled by net short-wave radiation and the radiation flux prevailed in the correlations between melt energy and temperature. Despite the small variations in ice albedo, temperature was still poorly correlated to melt energy $\left(\mathrm{r}^{2}(T, S E B)=0.17\right)$. On tropical glaciers, the frequent snowfalls during the melt season are not the main cause of the low correlations between air temperature and melting.

[49] On Storglaciären in summer 2000, the winter snowpack remained at the weather station until the end of July when ice became exposed (Figure 3). In August, a few snowfall events, not associated with large temperature drops, caused temporary small albedo rises. The change in albedo from snow to ice was more related to the initial snow depth and the accumulated melt than to the temperature while the snow was disappearing. As on Zongo, but for different reasons, the albedo changes did not favor the correlations of temperature with net short-wave radiation $((\mathrm{r}(T, S \downarrow)>$ $\mathrm{r}(T, S)$; Table 4) and thus participated in the small contribution of net short-wave radiation to the correlation between melt energy and temperature (Table 5). In summer 1999, snow remained on Storglaciären for a longer period of time and the calculations were conducted for a continuous snow-cover from 9 June to 10 July (Table 1). The correlations were similar to what was observed in summer 2000 except that the reduced variations in albedo caused better correlations of temperature with melt energy in 1999 (Table 5).

\section{Conclusion}

[50] This study investigated the correlations at a daily time scale of the energy fluxes with each other and with air temperature on three glaciers in contrasting climates: Zongo $\left(16^{\circ} \mathrm{S}\right.$, Bolivian outer tropics $)$, St Sorlin $\left(45^{\circ} \mathrm{N}\right.$, French Alps $)$, and Storglaciären $\left(67^{\circ} \mathrm{N}\right.$, northern Sweden). The results indicate distinct relationships between temperature, energy fluxes and total melt energy in the different climate settings.

[51] At tropical Zongo Glacier, net short-wave radiation controls the variability of the energy balance and is poorly correlated to air temperature. The turbulent flux of sensible heat is generally a gain in energy for the glacier surface, whereas the latent heat flux is a sink. Both turbulent fluxes tend to cancel each other out during the melt season. Air temperature is a poor index of melt because of (1) low and only slightly varying temperatures during the melt period and (2) the low heat content of the air at very high elevations. Albedo changes due to frequent snowfalls that temporarily cover the melting ice surface contribute to, but are not the main cause of, the poor correlations between temperature and melt energy. The degree-day model is not appropriate for simulating the melting of tropical glaciers at short time steps. At the yearly time scale, air temperature is a better index of the glacier mass balance because it integrates ablation and accumulation processes over a long time period.

[52] At St Sorlin glacier in the Alps, the turbulent sensible heat flux is more important mainly because of higher air temperatures in summer, but the variability of melt energy is still controlled by short-wave radiation. Air temperature is correlated to melt energy mainly through the net short-wave radiation, probably linked to diurnal advection of warm air from the valley.

[53] At high latitudes, this analysis on Storglaciären supports the conclusions of Braithwaite [1981], who found that high correlations between temperature and melt rate result from the large variability and close correlations with air temperature of the sensible heat flux. However, Braithwaite [1981] neglected the stability correction in the calculations of the turbulent fluxes, so that his study may overestimate the correlations between sensible heat flux and temperature. The turbulent fluxes controlled the variations of melt energy on Storglaciären because (1) short-wave irradiance is reduced by low sun elevation and frequent clouds, (2) the glacier is located at relatively low elevation where air temperature is high in summer, and (3) condensation due to humid air provides energy to the glacier's surface.

[54] This analysis does not corroborate the hypotheses of Ohmura [2001]. The long-wave irradiance is the main energy source, but it does not vary much and is poorly correlated to temperature. In high mountains, cloud emissions tend to control the variability of long-wave irradiance, causing negative correlations of long-wave irradiance with melting and with air temperature.

[55] Measurement errors may underestimate the contribution of the turbulent fluxes to the correlations of melting energy with temperature. Spurious self-correlations between the turbulent fluxes derived from the bulk method and air temperature are difficult to avoid and tend to overestimate this 
contribution. The overall effect of these errors is difficult to evaluate. On St Sorlin glacier, eddy covariance turbulent fluxes gave similar correlations with temperature than the bulk method, suggesting that the influence of spurious self-correlations remains small when air stability correction is included.

[56] Acknowledgments. The measurement programs on Zongo and St Sorlin were supported by the French ORE network GLACIOCLIM and the ANR project TAG ("Turbulence et Ablation Glaciaire", French Ministry of Research). The authors are grateful for the assistance received from IHH (Instituto de Hidraulica e Hídrologia) and UMSA (Universidad Mayor de San Andrés) in La Paz. We are grateful to Dr. Patrick Wagnon, Jean-Philippe Chazarin, and Edouard Perroy for the fieldwork and the meteorological station maintenance in Bolivia and France. We thank Dr. Vincent Favier who provided the data for Antizana, Ecuador. The authors are also grateful to two anonymous reviewers for making useful comments on the manuscript.

\section{References}

Braithwaite, R. J. (1981), On glacier energy balance, ablation, and air temperature, J. Glaciol., 27(97), 381-391.

Braithwaite, R. J. (1995), Positive degree-day factors for ablation on the Greenland ice sheet studied by energy-balance modelling, J. Glaciol., 41(137), 153-160.

Braithwaite, R. J., and Y. Zhang (1999), Modelling changes in glacier mass balance that may occur as a result of climate changes, Geogr. Ann., $81 A(4), 489-496$.

Braun, L. N., and C. B. Renner (1992), Application of a conceptual runoff model in different physiographic regions of Switzerland, Hydrol. Sci. J., $37(3), 217-231$.

Brett, M. T. (2004), When is a correlation between non-independent variables "spurious"?, Oikos, 105(3), 647-656.

Brutsaert, W. (1982), Evaporation Into the Atmosphere, Theory, History and Applications, 1st ed., 299 pp., Kluwer, Dordrecht, Netherlands.

Dagnelie, P. (1975), Théorie et Méthodes Statistiques. Applications Agronomiques, vol. II, 463 pp., Les Presses Agronomiques de Gembloux ed., Gembloux, Belgium.

De Woul, M., and R. Hock (2005), Static mass-balance sensitivity of Arctic glaciers and ice caps using a degree-day approach, Ann. Glaciol., 42, 217-224.

Favier, V., P. Wagnon, J. P. Chazarin, L. Maisincho, and A. Coudrain (2004), One-year measurements of surface heat budget on the ablation zone of Antizana glacier 15, Ecuadorian Andes, J. Geophys. Res., 109(D18), D18105, doi:10.1029/2003JD004359.

Granger, R. J., and D. H. Male (1978), Melting of a prairie snowpack, J. Appl. Meteorol., 17(12), 1833-1842.

Hock, R. (1999), A distributed temperature index ice and snow melt model including potential direct solar radiation, J. Glaciol., 45(149), 101-111.

Hock, R. (2003), Temperature index modelling in mountain areas, J. Hydrol., $282,104-115$.

Hock, R., and B. Holmgren (2005), A distributed surface energy-balance model for complex topography and its application to Storglaciären, Sweden, J. Glaciol., 51(172), 25-36.

Hoinkes, H. C. (1955), Measurements of ablation and heat balance on alpine glaciers, J. Glaciol., 2(17), 497-501.

Hostetler, S. W., and P. U. Clark (2000), Tropical climate at the last glacial maximum inferred from glacier mass-balance modeling, Science, 290(1), $1747-1750$

Johanneson, T., O. Sigurdsson, T. Laumann, and M. Kennett (1995), Degree-day glacier mass-balance modelling with applications to glaciers in Iceland, Norway and Greenland, J. Glaciol., 41(138), 345-358.

Jonsell, U., R. Hock, and B. Holmgren (2003), Spatial and temporal variations in albedo on Storglaciären, Sweden, J. Glaciol., 49(164), 59-68.

Kaser, G. (2001), Glacier-Climate interaction at low latitudes, J. Glaciol., 47(157), 195-204.

Kenney, B. C. (1982), Beware of spurious self-correlations!, Water Resour. Res., 18(4), 1041-1048.

Kramer, Y. (2001), Investigation on Surface Energy Fluxes and Their Relationship to Synoptic Weather Patterns on Storglaciaren, Northern Sweden. Examensarbete, 43 pp., Dept. of Earth Sci., Uppsala Univ., Uppsala, Sweden.

Kuhn, M. (1993), Methods of assessing the effects of climate changes on snow and glacier hydrology, IAHS, 218, 135-144.

Kull, C., and M. Grosjean (2000), Late Pleistocene climate conditions in the north Chilean Andes drawn from a climate-glacier model, J. Glaciol., $46(155), 622-632$.
Kustas, W. P., A. Rango, and R. Uijlenhoet (1994), A simple energy budget algorithm for the snowmelt runoff model, Water Resour. Res., 30(5), $1515-1527$

Kuusisto, P. P. (1980), On the values and variability of degree-day melting factors in Finland, Nordic Hydrol., 11(5), 235-242.

La Casinière de, A. C. (1974), Heat exchange over a melting snow surface, J. Glaciol., 13(67), 55-72.

Lang, H., and L. Braun (1990), On the information content of air temperature in the context of snow melt estimation, IAHS, 190, 347-354.

Laumann, T., and N. Reeh (1993), Sensitivity to climate change of the mass balance of glaciers in southern Norway, J. Glaciol., 39(133), 656-665.

Martin, S. (1977), Analyse et reconstitution de la série des bilans annuels du glacier de Sarennes, sa relation avec les fluctuations du niveau des trois glaciers du massif du Mont-Blanc (Bossons, Argentière, Mer de glace), Z. Gletscherkunde Glazialgeologie, 13(1/2), 127-153.

Meesters, A. G. C. A., N. J. Bink, H. Vugts, F. Cannemeijer, and E. A. C. Henneken (1997), Turbulence observations above a smooth melting surface on the Greenland ice sheet, Boundary-Layer Meteorol., $85,81-110$

Obled, C., and B. Rosse (1975), Modèles mathématiques de la fusion nivale en un point, Cah. l'ORSTOM, Ser. Hydrolog., XII(4), 235-252.

Ohmura, A. (2001), Physical basis for the temperature-based melt-index method, J. Appl. Meteorol., 40, 753-761.

Pellicciotti, F., B. Brock, U. Strasser, P. Burlando, M. Funk, and J. Corripio (2005), An enhanced temperature-index glacier melt model including the shortwave radiation balance: Development and testing for Haut Glacier d'Arolla, Switzerland, J. Glaciol., 51(175), 573-587.

Pellicciotti, F., J. Helbing, A. Rivera, V. Favier, J. Corripio, J. Araos, J. E. Sicart, and M. Carenzo (2008), A study of the energy balance and melt regime on Juncal Norte Glacier, semi-arid Andes of central Chile, using melt models of different complexity, Hydrol. Processes, 22(19), 3980-3997.

Pouyaud, B., M. Zapata, J. Yerren, J. Gomez, G. Rosas, W. Suarez, and P. Ribstein (2005), On the future of the water resources from glacier melting in the Cordillera Blanca, Peru, Hydrolog. Sci. J., 50(6), 9991022 .

Sicart, J. E., P. Ribstein, J. P. Chazarin, and E. Berthier (2002), Solid precipitation on a tropical glacier in Bolivia using ultrasonic depth gauge measurements, Water Resour. Res., 38(10), 1189, doi:10.1029/ 2002WR001402.

Sicart, J. E., P. Wagnon, and P. Ribstein (2005), Atmospheric controls of the heat balance of Zongo Glacier $\left(16^{\circ} \mathrm{S}\right.$, Bolivia), J. Geophys. Res., 110, D12106, doi:10.1029/2004JD005732.

Sicart, J. E., J. W. Pomeroy, R. L. H. Essery, and D. Bewley (2006), Incoming long-wave radiation to melting snow: Observations, sensitivity and estimation in northern environments, Hydrol. Processes, 20(17), $3697-3708$

Sicart, J. E., P. Ribstein, B. Francou, B. Pouyaud, and T. Condom (2007), Glacier mass balance of tropical Zongo Glacier, Bolivia, comparing hydrological and glaciological methods, Global Planet. Change, 59(1), $27-36$.

Singh, P., and N. Kumar (1996), Determination of snowmelt factor in the Himalayan region, Hydrolog. Sci. J., 41(3), 301-310.

Six, D., P. Wagnon, J. E. Sicart, and C. Vincent (2008), Meteorological controls on surface energy balance on Saint-Sorlin Glacier (France), ablation season 2006, Ann. Glaciol., 50, in press.

U.S. Army Corps of Engineers (1956), Summary Report of the Snow Investigations, Snow Hydrology, North Pacific Division, Portland, Oreg.

Wagnon, P., P. Ribstein, B. Francou, and B. Pouyaud (1999), Annual cycle of energy balance of Zongo Glacier, Cordillera Real, Bolivia, J. Geophys. Res., 104(D4), 3907-3923.

Wagnon, P., P. Ribstein, B. Francou, and J. E. Sicart (2001), Anomalous heat and mass budget of Glaciar Zongo, Bolivia, during the 1997/98 El Nino year, J. Glaciol., 47(156), 21-28.

Woo, M. K., and B. B. Fitzharris (2001), Reconstruction of mass balance variations for Franz Josef Glacier, New Zeland, 1913-1989, Arctic Alp. Res., 24, 281-290.

Zuzel, J. F., and L. M. Cox (1975), Relative importance of meteorological variables in snowmelt, Water Resour. Res., 11(1), 174-176.

R. Hock, Geophysical Institute, University of Alaska, Koyukuk Drive, P.O. Box 757320, Fairbanks, AK 99775-7320, USA. (regine.hock@gi. alaska.edu)

J. E. Sicart, Great Ice-IRD, Case MSE, Université Montpellier II, 300, Avenue du Professeur Emile Jeanbrau, 34095 Montpellier Cedex 5, France. (sicart@msem.univ-montp2.fr)

D. Six, Laboratoire de Glaciologie et Géophysique de l'Environnement, University Joseph Fourier, 54 rue Molière-BP 96-38402 Saint Martin d'Hères Cedex, Grenoble, France. (six@lgge.obs.ujf-grenoble.fr) 